\title{
Anti-inflammatory (invitro) activity of the Leaves of Ficus gibbosa Blume.by HRBC Membrane stabilisation
}

\author{
P.L.Rajagopal ${ }^{a^{*}}$, K.R.Sreejith ${ }^{\mathrm{a}}$, S.S. Kiron ${ }^{\mathrm{b}}$, RobinJose ${ }^{\mathrm{C}}$, M.Saritha ${ }^{\mathrm{d}}$ \\ *aAsst.Professor, Department of Pharmacognosy, Academy of Pharmaceutical Sciences, Pariyaram Medical \\ College, Kannur, Kerala, S.India. \\ a Asst. Professor, Department of Pharmaceutical Chemistry, Academy of Pharmaceutical Sciences, Pariyaram \\ Medical College, Kannur, Kerala, S.India. \\ ${ }^{b}$ Asst.Professor, Department of Pharmacy Practice, Academy of Pharmaceutical Sciences, Pariyaram Medical \\ College, Kannur, Kerala, S.India. \\ ${ }^{c}$ Professor, Department of Pharmacentical Chemistry,Academy of Pharmaceutical Sciences, Pariyaram \\ Medical College, Kannur, Kerala, S.India. \\ ${ }^{d}$ Asst.Professor, Department of Pharmacy Practice, Crescent B.Pharm College, Payangadi, Kannur, Kerala, \\ S.India.
}

\begin{abstract}
Plants have been used as alternative remedy for the treatment of various ailments since ancient times. Phytochemical analysis, and in vitro anti-inflammatory activity of leaf extract of Ficus gibbosa were studied. The methanolic leaf extract was tested for the presence of phytochemicals. Phytochemical screening reveals the presence of saponins, tannins, glycosides, alkaloids and flavonoids. Since many flavonoids have remarkable anti inflammatory activity the present work aims at evaluating the anti inflammatory activity of Ficus gibbosa by HRBC membrane stabilization.

Key Words: Anti-inflammatory, Ficus gibbosa, HRBC Membrane stabilisation.
\end{abstract}

\section{Introduction}

Inflammation was considered as a single disease caused by disturbances of body flluids. The modern concept of inflammation is based on the theory of John Hunter who considered inflammation to be salutary operation, resulting from some disease. Inflammation can be defined as the reaction to injury of the living microcirculation and related tissues. Inflammation is a normal protective response to tissue injury and it involves a complex array of enzyme activation, mediator release, cell migration, tissue breakdown and repair (Vane et al., 1995).It is a complex process, which is frequently associated with pain and involves occurrences such as: the increase in vascular permeability, increase of protein denaturation and membrane alterations (Umapathy et al., 2010).

Ficus gibbosa is a small, at time large tree often epiphytic or climbing, enclosing the trunks of trees in a perfect network of brfanches or creeping a long walls and on the sides of wells. The decoction of the root act as a powerful aperient.

\section{Plant material}

\section{Materials And Methods}

The Fresh leaves of Ficus gibbosa were collected from the Medicinal garden of Academy of Pharmaceutical Sciences, Pariyaram, Kannur, Kerala in January 2013. The plant material was identified and and a voucher specimen (FGBL) was deposited in the herbarium of the Department of Pharmacognosy of Academy of Pharmaceutical Sciences.

\section{Preparation of extracts}

The leaves were dried under shade and powdered. The powder was transfered to soxhlet extractor and subjected to extraction with ethanol. After extraction, the solvent was distilled off and the extract was concentrated on water bath to a dry residue and kept in a desiccator.

\section{Anti-Inflammatory Activity}

The HRBC membrane stabilization has been used as a method to study the anti inflammatory activity. (Gandidasan.R, 1991) Blood was collected from healthy volunteers. The collected blood was mixed with equal volume of sterilized Alsever solution The blood was centrifuged at $4000 \mathrm{rpm}$ and packed cells were washed with isosaline and a $10 \% \mathrm{v} / \mathrm{v}$ suspension was made with isosaline. The assay mixture contains the drug at various concentration , $1 \mathrm{ml}$ phosphate buffer, $2 \mathrm{ml}$ of hyposaline and $0.5 \mathrm{ml}$ of HRBC suspension. Indomethacine was used as the reference drug. Instead of hyposaline $2 \mathrm{ml}$ of distilled water was used in the 
control. All the assay mixtures were incubated at $37^{\circ} \mathrm{c}$ for $30 \mathrm{~min}$ and centrifuged. The haemoglobin content in the supernatant solution was estimated by using spectrophotometer at $560 \mathrm{~nm}$. The percentage hemolysis was calculated by assuming the hemolysis produced in the presence of distilled water as $100 \%$. The percentage of HRBC membrane stabilization or protection was calculated by using the formula,

Percentage Protection $=100-($ OD sample $/ O D$ Control $) \times 100$

*OD=Optical Density

\section{Results}

Table 1 Phytochemical screening of ethanolic extract of Ficus gibbosa

\begin{tabular}{|c|c|c|}
\hline Sl No & Phytoconstituents & Ethanolic Extract of the Leaves \\
\hline 1 & Flavonoids & + \\
\hline 2 & Carbohydrates & + \\
\hline 3 & Tannins & + \\
\hline 4 & Alkaloids & + \\
\hline 5 & Glycosides & + \\
\hline 6 & Saponins \\
\hline \multicolumn{2}{|c|}{+ Positive (Present) } \\
\hline
\end{tabular}

Table 2 Anti inflammatory activity of Ficus gibbosa at various concentrations

\begin{tabular}{|c|c|c|c|}
\hline \multirow{2}{*}{$\begin{array}{c}\text { Sl } \\
\text { No }\end{array}$} & $\begin{array}{c}\text { Concentration } \\
\mathrm{mg} / \mathrm{ml}\end{array}$ & \multicolumn{2}{|c|}{ Anti-inflammatory activity(\%Protection) } \\
\cline { 3 - 4 } & & Ethanolic Extract of Ficus gibbosa & $\begin{array}{c}\text { Standard } \\
\text { Indomethacin }\end{array}$ \\
\hline 1 & Control & ---- & ---- \\
\hline 2 & 100 & $57.4 \pm 0.03$ & $74.93 \pm 0.02$ \\
\hline 3 & 200 & $60.2 \pm 0.04$ & $84.86 \pm 0.04$ \\
\hline 4 & 300 & $63.3 \pm 0.06$ & $89.20 \pm 0.09$ \\
\hline 5 & 400 & $71.2 \pm 0.02$ & $92.35 \pm 0.01$ \\
\hline 6 & 500 & $77.3 \pm 0.05$ & $94.10 \pm 0.04$ \\
\hline
\end{tabular}

(Values are expressed as SEM of 3 readings)

\section{Discussions}

The alcoholic extract of Ficus gibbosa subjected to erythrocyte (RBC) membrane stabilization induced haemolysis by hypotonic solution. The erythrocyte membrane resembles to lysosomal membrane and as such the erythrocyte could be extrapolated to the stabilization of lysosomal membrane (Omale et al., 2008). The extra cellular activity of the lysosomal enzymes is said to be related to acute or chronic inflammation. The non steroidal drugs act either by inhibiting these lysosomal enzymes or by stabilizing the lysosomal membrane. (Rajendran Vadivu, 2008). It was observed from the table 2 that the ethanolic extract shows significant anti inflammatory activity at the concentration of $500 \mathrm{mg} / \mathrm{ml}$ which is comparable to the standard drug Indomethacin. The anti inflammatory activity of the extract was concentration dependent, with the increasing concentration the activity was also increased. The phytochemical screening of the extract revealed the presence of flavonoids, resins, tannins etc.The anti-inflammatory effect of the ethanolic extract may be due to the presence of flavonoids and saponins. Flavonoids and steroids show remarkable anti-inflammatory activity by inhibiting the cox and lox systems [Robert et al., 2001; Tapas et al., 2008).

\section{Conclusion}

This study reveals that, the ethanol fraction prepared from Ficus gibbosa leaves contains high amounts of total phenolics and total flavonoids and flavonoids are well documented to be having strong antioxidant activity and antiinflamatory activity. Thus, ethanol seems to be most promising solvent for extraction and isolation of natural antioxidative compounds from Ficus gibbosa leaves. Further studies in isolation of individual phenolic compounds particularly flavonoids in this fraction and its effect on antioxidant in animal models are needed to evaluate their potential benefits.

The ethanolic extract of the leaves exhibited membrane stabilization effect by inhibiting hypotonicity induced lysis of erythrocyte membrane. The erythrocyte membrane is analogus to the lysosomal membrane and its stabilization implies that the extract may as well stabilize lysosomal membrane.

From the above study it was concluded that the ethanolic extract of Ficus gibbosa has significant membrane stabilization property and it was comparable to the standard drug Indomethacin. 


\section{References}

[1]. Gandhidasan R, Thamaraichelvan.A,Baburaj.S. Anti inflammatory action of Lannea coromandelica by HRBC membrane stabilization. Fitoterapia.1991; Voll LXII; No1; pp.81-83.

[2]. Harborne J B (1973), Phytochemical Methods: A Guide to Modern Technique of Plant Analysis, Cambridge University Press, Cambridge, UK.

[3]. Umapathy E, Ndebia EJ , Meeme A, Adam B, Menziura P, Nkeh-Chungag BN and Iputo JE(2010).An experimental evaluation of Albuca setosa aqueous extract on membrane stabilization, protein denaturation and white blood cell migration during acute inflammation. Journal of Medicinal Plant Research 4 (5), pp.789-795.

[4]. Omale J and Okafor PN (2008).Comparative antioxidant capacity and cytotoxicity of the leaf and stem of Cissus multistriata. African Journal of Biotechnology 7(17), pp. 3129-3133.

[5]. Rajendran Vadivu, Lakshmi K.S. In vitro and in vivo anti inflammatory activity of leaves of Symplocos cochinchinensis (Lour) Moore ssp Laurina. Bangladesh J Pharmacol.2008; 3; pp.121-124.

[6]. Robert J, Nijveldt, Elsvan Nood, Danny EC and van Hoorn (2001), "Flavonoids: A Review of Probable Mechanisms of Action and Potential Applications", Am. J. Clin. Nut., Vol. 74, pp. 418-425.

[7]. Tapan Kumar Chatterjee (1996), Herbal options, Esatern Traders,Calcutta,pp.157-161.

[8]. Tapas A R, Sakarkar D M and Kakde R B (2008), "Flavonoids as Nutraceuticals", A Review, Tropical Journal of Pharmaceutical Research., Vol. 7, No. 3, pp. 1089-1099.

[9]. Vane JR (1971). Inhibition of prostaglandins synthesis as a mechanism of action for aspirin like drugs. Nature 231(2), pp. $232-235$.

[10]. Vane JR and Botting RM (1995).New insights into the mode of action of anti-inflammatory drugs. Inflammation Research 44 (1), pp. $1-10$. 